\title{
Experimental and Numerical Analysis of a Waste Cooking Oil Biodiesel Blend used in a Compression Ignition Engine
}

\author{
Sıkıştırma Ateşlemeli Bir Motorda Kullanılan Atık Yemek Yağı Biyodizel Karışımının \\ Deneysel ve Sayisal Analizi
}

\author{
Ramazan ŞENER ${ }^{1}$ \\ ${ }^{1}$ Batman University, Automotive Engineering Department, 72100, Batman, Turkey
}

\begin{abstract}
It is necessary to meet increasingly stringent emission standards of IC engines, reducing the emission values. While improving engine parameters and combustion chamber geometries can reduce emissions, also the research continues for alternative fuels. Biodiesel production from waste cooking oils has advantages in terms of recycling, environment, and cost. Waste cooking oils can be used as fuel in compression ignition (CI) engines with minor modifications. Biodiesel can be used in neat form or blend with diesel. In this way, there is no need to make any modifications to the existing diesel engines. In this study, diesel was blended with biodiesel at 20\% (B20) and it was used as fuel in a CI engine. The performance and emission values of this blend were compared according to neat diesel fuel. As a result of the experimental and CFD simulation studies, it was observed that the use of the B20 fuel blend reduced $\mathrm{CO}$ emissions by $22.7 \%$ and soot emissions by $15.6 \%$. In addition, the maximum pressure inside the cylinder has decreased by $2.7 \%$.
\end{abstract}

Keywords: CI engine, waste cooking oil, biodiesel, CFD, emission.

Öz

İçten yanmalı motorların emisyon değerlerinin azaltılması, gittikçe katılaşan standartların karşılanması için gereklidir. Motor parametreleri ve yanma odası geometrilerinin iyileştirilmesi emisyonları azaltabileceği gibi, alternatif yakıt arayışları da sürmektedir. Atık yemek yağlarından biyodizel üretimi, hem geri dönüşüm ve çevre duyarlılı̆̆ bakımından hem de maliyet bakımından avantajları olmaktadır. Atık yemek yağlar, küçük modifikasyonlarla, yakıt olarak kullanılabilecek duruma gelmektedir. Üretilen biyodizel saf halde kullanılabileceği gibi, dizel ile karıştırılarak kullanılabilmektedir. Bu şekilde, mevcut dizel motorlarda herhangi bir modifikasyon yapmaya gerek kalmamaktadır. Bu çalışmada, \%20 oranında biyodizel, dizel ile karıştırılarak, yakıt olarak sıkıştırma ateşlemeli bir motorda kullanılmıştır ve saf dizel yakıt kullanıma göre performans ve emisyon değerleri karşılaştırılmıştır. Deneysel ve CFD simülasyon çalışmaları sonucunda, B20 yakıt karışımı kullanımıyla, $\mathrm{CO}$ emisyonlarında \%22.6 ve is emisyonlarında \% 15.6 oranında azalma gözlemlenmiştir. Ayrıca silindir içi maksimum basınç, $\% 2.7$ oranında azalmıştır.

Anahtar Kelimeler: S1kıştırma ateşlemeli motor, atık yemek yağı, biyodizel, HAD, emisyon.

\section{INTRODUCTION}

Internal combustion engines struggle to meet increasingly stringent emission standards. In order to cope with these emission standards, very high-efficiency internal combustion engines need to be produced. It is aimed to reduce exhaust emissions that threaten human health. To increase engine efficiency, it is important to optimize the injection parameters and to design the optimum combustion chamber, while reducing emission value can be achieved by using alternative fuels.

Among alternative fuels, biodiesel is promising because of biodegradable, requiring only slight modification, and does not contain sulfur or aromatics [1]. Biodiesel is a safer fuel because it has a high flash point [2]. It is also biodegradable, non-toxic, and better lubricity [3]. The most important disadvantage of biodiesel is the high cost hereby it is not common to use [4,5]. Of course, the waste cooking oil (WCO) has a lower cost than virgin oils, it can be produced at about $45 \%$ lower cost [6-8]. It has similar emission characteristics to other types of biodiesel. The WCO biodiesel burns with lower temperatures, thus resulting in lower $\mathrm{NO}_{\mathrm{x}}$ emission [9-12]. However, in some other studies, $\mathrm{NO}_{\mathrm{X}}$ increases and soot emissions decrease compared to the known high $\mathrm{NO}_{\mathrm{X}}$ profile of biodiesel [13-17].

The combustion chamber design is important for emission formation. In this regard, experimental studies give a limited understanding of emission formation and the contribution of engine geometry to emission formation.

Corresponding Author: Ramazan ȘENER, Tel: +904882 174029, e-posta: ramazan.sener@batman.edu.tr

Submitted: 20.1I.2020, Revised: 09.03.2021, Accepted: 09.03.2021 
In addition, the reason for the results is no more than assumptions. Herein computational fluid dynamics (CFD) simulations provide a satisfactory and deep insight into the oxidation and emission generation [1821]. Also after validation of numerical results, some modifications and new setups can be investigated by simulations [22]. Venu et al. investigated the combustion chamber geometry of alumina added biodiesel-diesel-ethanol fueled on Diesel-RK software and it was found that toroidal re-entrant combustion chamber improves combustion efficiency [23]. Ismail et al. used the Comment code for the numerical study of jatropha and canola-fueled diesel engines. Performance results correspond with experimental results successfully, with a $2.7 \%$ error [24]. Asadi et al. investigated the effect of biodiesel premixing on performance and emission with AVL Fire commercial code. According to results, premixing biodiesel results in lower soot and higher $\mathrm{NO}_{\mathrm{X}}$ [25]. Rajak et al. have been conducted nine different biofuels fueled diesel engines on Diesel-RK. It is concluded that biofuels have lower soot and smoke profile than neat diesel [26]. Zhao et. al studied unsaturated biodiesels' effects on the mass and size of soot by KIVA4-Chemkin software. According to results, biodiesels suppress the formation of soot. However, it is found that unsaturation raises soot formation regarding mass and size [27]. Akçay et. al investigated a compression ignition (CI) engine fueled with the diesel-WCO biodiesel blend and adding hydrogen to intake air. They obtained that $\mathrm{NO}_{\mathrm{X}}$ and $\mathrm{HC}$ emissions decreased on low and medium loads with the hydrogen addition while and break specific fuel consumption (BSFC) decreased for all working conditions [28].

In order to see the contribution of the combustion engine design as well as fuel properties in emission formation, in this study, the Converge CFD commercial code was used. WCO biodiesel was selected as an alternative fuel and $20 \%$ biodiesel - $80 \%$ diesel was chosen for CFD analyses since the best results obtained from this blend regarding reduction in all emissions and minimum BSFC according to experimental studies.

\section{MATERIAL AND METHOD}

\subsection{Biodiesel Production}

The transesterification method is used for waste cooking oil-based biodiesel production. This method consists of filtration to remove solid materials from waste cooking oil (WCO), heating to evaporate and remove water from WCO, dissolving alkalis as catalysts in alcohol solutions, mixing to make catalystcontaining alcohol solutions. Fig. 1 shows the schematic of biodiesel production. The properties of diesel and WCO-biodiesel used in this study are given in Table 1. Biodiesel has lower LHV, and higher density compared to diesel.

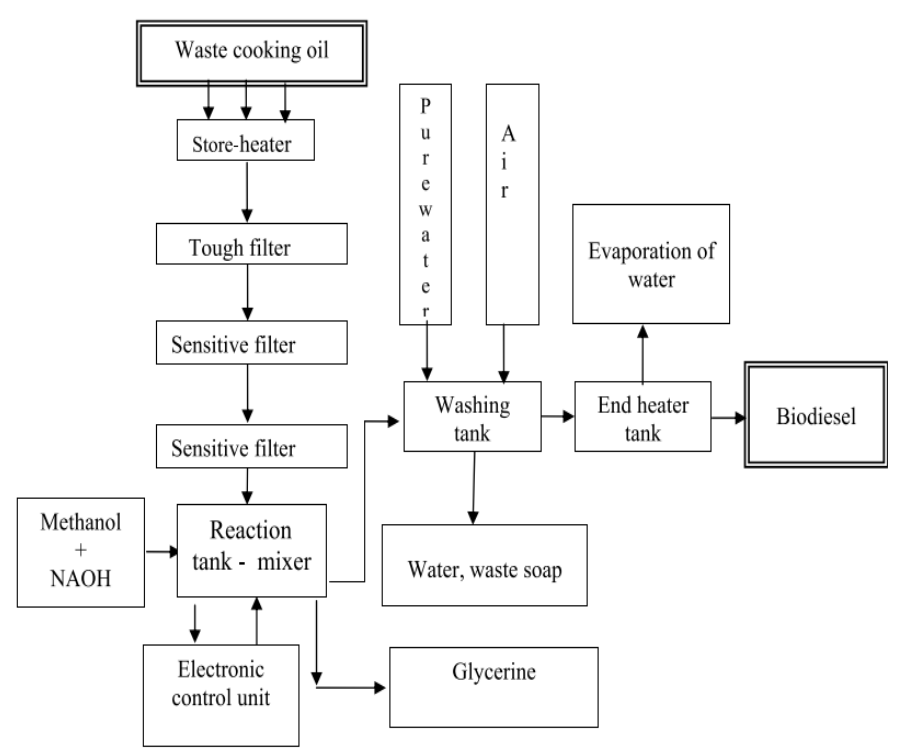

Figure 1. Schematic of the biodiesel production from waste cooking oil [29].

Table 1. Properties of diesel and WCO-biodiesel.

\begin{tabular}{lccc}
\hline Property & Diesel & B20 & $\begin{array}{c}\text { WCO- } \\
\text { Biodiesel }\end{array}$ \\
\hline Density $\left[\mathrm{kg} / \mathrm{m}^{3}\right]$ & 842 & 849 & 879 \\
$\begin{array}{l}\text { Cetane number }[-] \\
\begin{array}{l}\text { Kinematic viscosity } \\
{\left[\mathrm{mm}^{2} / \mathrm{s}\right]}\end{array}\end{array}$ & 54.9 & 55.3 & 56.7 \\
$\begin{array}{l}\text { Cloud point }\left[{ }^{\circ} \mathrm{C}\right] \\
\begin{array}{l}\text { Lower heating value } \\
{[\mathrm{MJ} / \mathrm{kg}]}\end{array}\end{array}$ & -42.3 & -2.2 & 6.21 \\
\begin{tabular}{l} 
Flash point $\left[{ }^{\circ} \mathrm{C}\right]$ \\
\hline
\end{tabular} & 92.5 & 110.4 & 182.0 \\
\hline
\end{tabular}

\subsection{Experimental Setup}

Experiments were conducted to evaluate the performance and emission of diesel and WCO-based biodiesel fuels using a single-cylinder, four-stroke, direct injection, and water-cooled, naturally aspirated diesel engine. Experiments have been performed in Engine Research Laboratory, Yildiz Technical University. The experimental setup is shown in Fig. 2 and the specifications of the engine are referred to as Table 2.

Table 2. Test Engine Specifications.

\begin{tabular}{lc}
\hline Engine model and type & $\begin{array}{c}\text { Single Cylinder, four-stroke, } \\
\text { Compression Ignition and } \\
\text { naturally aspirated }\end{array}$ \\
\hline Total displacement & $510 \mathrm{~cm}^{3}$ \\
Bore / Stoke & $85 / 90 \mathrm{~mm}$ \\
Connecting rod length & $144.5 \mathrm{~mm}$ \\
Compression ratio & 17.5 \\
Max. Power & $9 \mathrm{~kW}$ at $2700 \mathrm{rpm}$ \\
Max. Torque & $32 \mathrm{Nm}$ at $1800 \mathrm{rpm}$ \\
Injection type & mechanical, $20 \mathrm{MPa}$ \\
Cooling & water \\
\hline
\end{tabular}


The test engine was coupled with Kemsan $20 \mathrm{~kW}$ electrical dynamometer using Esit branded load cell to measure torque. In-cylinder pressure was measured using an AVL QC34D piezoelectric sensor with a water-cooled. Indismart Gigabit amplificatory was used to amplify obtained voltages from the pressure sensor. Crank angle determination was carried out by AVL 365c encoder. Collected values from the encoder and amplificatory rendered by AVL Indicom v2.4 software. Krohne Optimas 3400 flowmeter was used for fuel mass flow measurement. In addition, exhaust and cooling water temperatures are measured by Tekon TT model thermocouples.

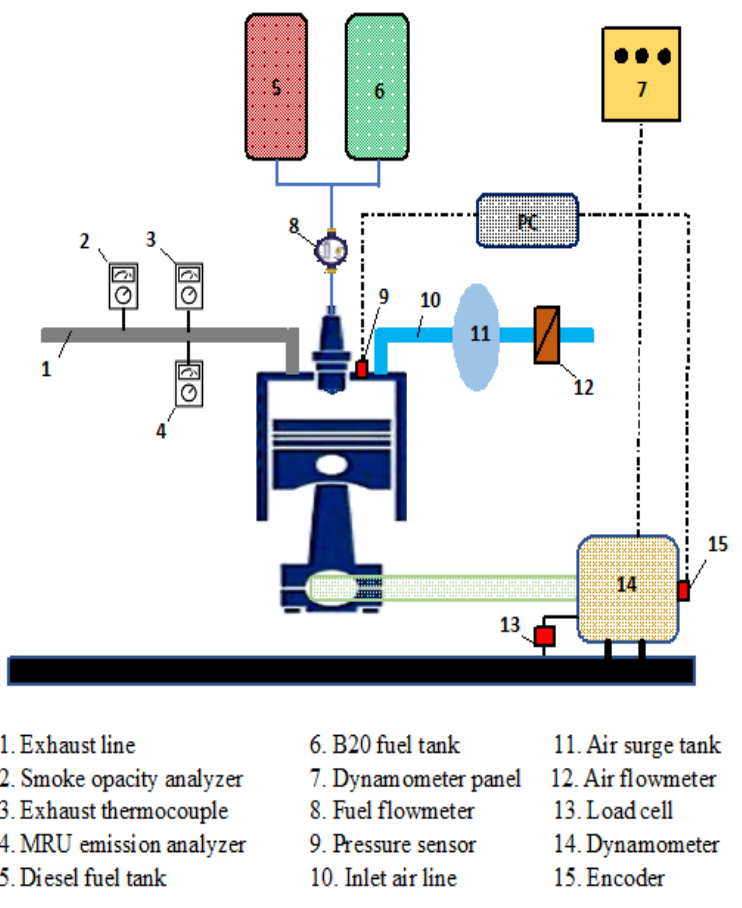

Figure 2. Schematic view of the experimental setup
Exhaust emissions were measured by MRU gas analyzer, which has $10 \mathrm{ppm}, 0.03 \%, 0.5 \%, 5 \mathrm{ppm}, 5$ ppm measurement sensitivity for $\mathrm{CO}, \mathrm{HC}, \mathrm{CO}_{2}, \mathrm{NO}_{2}$, and NO. In addition, Bosch BAE 070 gas analyzer was used to measure diesel smoke opacity (Table 3).

Table 3. Measurement range and sensitivity of exhaust emissions.

\begin{tabular}{ccc}
\hline Emissions & Sensitivity & Measurement range \\
\hline $\mathbf{H C}$ & $\% 0.03$ & $0-10000 \mathrm{ppm}$ \\
$\mathbf{C O}{ }_{2}$ & $\% 0.5$ & $\% 0-30$ \\
$\mathbf{C O}$ & $10 \mathrm{ppm}$ & $0-4000 \mathrm{ppm}$ \\
$\mathbf{N O}_{2}$ & $5 \mathrm{ppm}$ & $0-200 \mathrm{ppm}$ \\
$\mathbf{N O}$ & $5 \mathrm{ppm}$ & $0-1000 \mathrm{ppm}$ \\
\hline
\end{tabular}

Experiments were performed at full load and $2700 \mathrm{rpm}$. The biodiesel ratio in the blend was chosen as $20 \%$ and compared with neat diesel. Measurements were started after exhaust temperatures reach stable conditions. Incylinder pressure values were averaged over 50 cycles.

\subsection{CFD Model}

The CFD simulations of the test engine were performed using the Converge CFD tool [30]. The piston bowl of the engine was asymmetrical, however, the full engine with intake and exhaust ports and sector mesh geometries were used for an accurate model. The fluid geometry of the test engine is extracted from the solid body (fig. 3). The domain was meshed with the modified cut-cell cartesian method. The adaptive mesh refinement (AMR) method was employed as a compromise between accuracy and computational runtime. The simulation flow process chart is illustrated in fig. 4 .

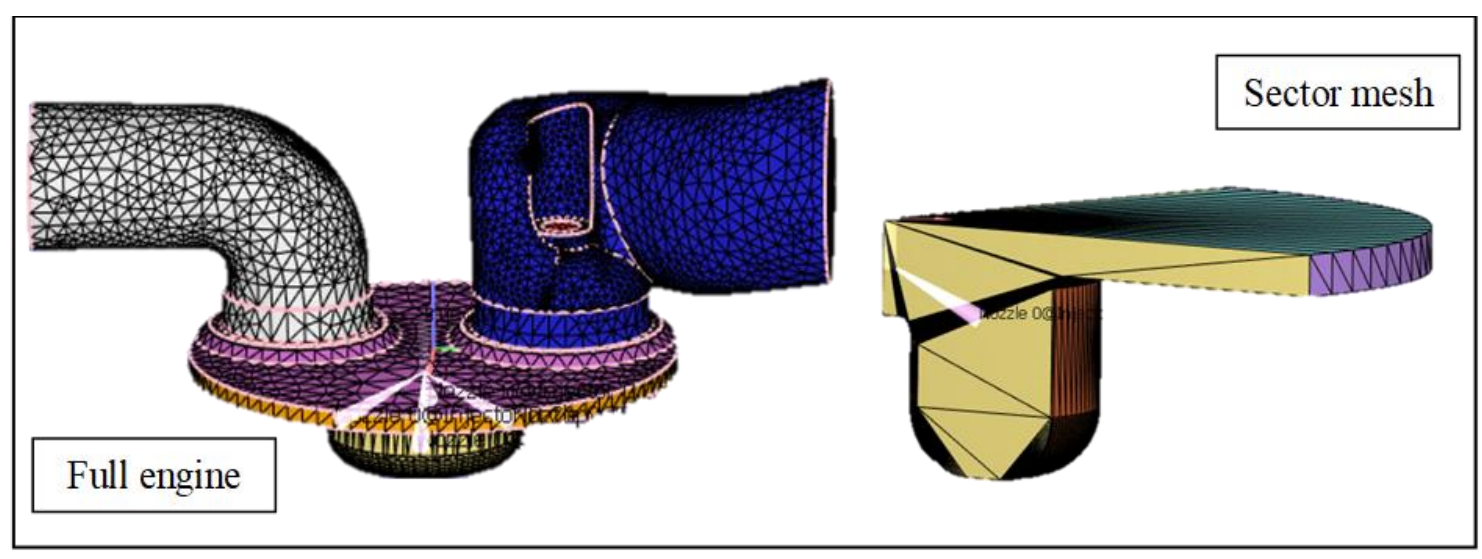

Figure 3. The fluid domain of the CFD model as a sector and full engine at TDC. 


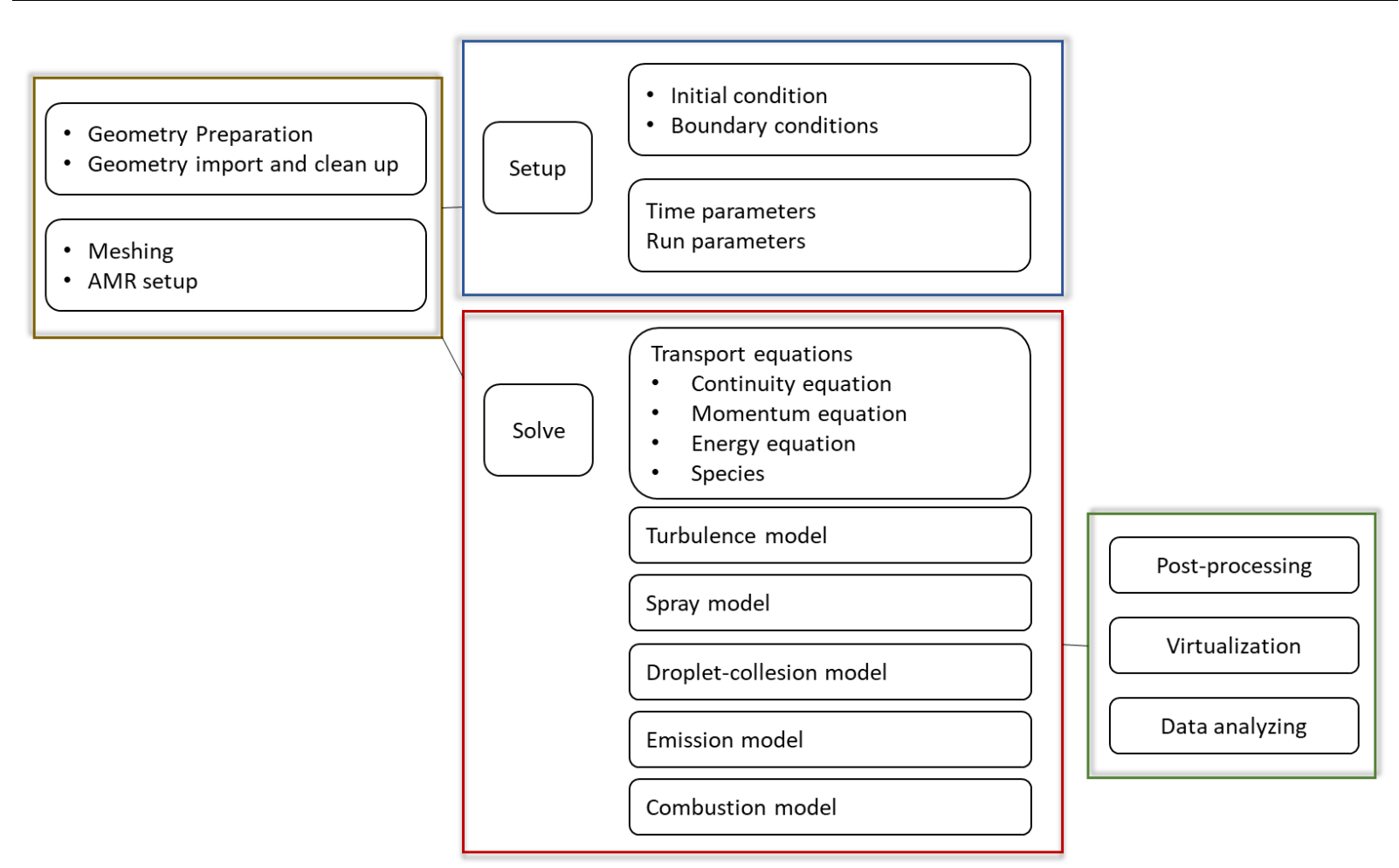

Figure 4. The flow chart of the CFD simulation.

The renormalization group (RNG) k- $\varepsilon$ model was used as a turbulence model to solve in-cylinder flow because of its accuracy and effectiveness [31]. A detailed chemistry solver (SAGE) was preferred with detailed chemical kinetics to model the in-cylinder combustion [32]. The reaction mechanism that able to predict the ignition delay, flame lift-off length and equivalence ratio under various conditions for biodiesel used in the simulations was developed by Lawrence Livermore National Laboratory (LLNL) [33]. This mechanism consists of 115 species and 460 reactions for a tricomponent biodiesel surrogate as methyl decanoate, $n$ heptane, and methyl 9-decenoate. The O'Rourke and Amsden model was selected to simulate the wall heat transfer [34]. The diesel and WOC-biodiesel were defined with fuel specifications in the CFD software. $2.0 \times 10^{5}$ of the drop parcels per injector hole were introduced to present an identical set of drops. The hybrid Kelvin-Helmholtz Rayleigh-Taylor (KH-RT) spray breakup mechanism was used to breakup processes and spray atomization $[35,36]$. The No Time Counter (NTC) method was used to model the collision process [37]. $\mathrm{NO}_{\mathrm{X}}$ formation was calculated utilizing the expanded Zeldovich mechanism [38]. Soot formation was estimated using the Hiroyasu-NSC empirical soot model [39].

The B0 (neat diesel) and B20 (20\% biodiesel $+80 \%$ diesel) were used to validate the experimental data. The test engine operating parameters were listed in table 4 . The experimental conditions were adopted to the CFD model.
Table 4. Test engine operating parameters.

\begin{tabular}{|c|c|}
\hline Pressure at IVC & $106.52 \mathrm{kPa}$ \\
\hline Temperature at IVC & $341.87 \mathrm{~K}$ \\
\hline IVC & $129^{\circ} \mathrm{bTDC}$ \\
\hline EVO & $137^{\circ}$ aTDC \\
\hline Fuel & $\begin{array}{c}\text { Diesel and WCO } \\
\text { Biodiesel }\end{array}$ \\
\hline Injected fuel mass & $\begin{array}{c}26.54 \mathrm{mg}(\mathrm{B} 0) \text { and } \\
27.3 \mathrm{mg}(\mathrm{B} 20)\end{array}$ \\
\hline SOI & $20^{\circ} \mathrm{bTDC}$ \\
\hline Injection pressure & $20 \mathrm{MPa}$ \\
\hline Compression ratio & $17.5: 1$ \\
\hline Spray angle & 120 gree \\
\hline
\end{tabular}

\section{RESULTS AND DISCUSSION}

\subsection{Combustion Characteristics}

Biodiesel has an important effect on reducing emissions with diesel mixture. According to previous studies, the B20 blend can be used without the need for a change on the $\mathrm{CI}$ engine and a significant reduction in the exhaust emissions can be achieved [40]. Results of B0 and B20 fuel blends experiments and the CFD simulation at full-load and $2700 \mathrm{rpm}$ were compared in fig. 5 and 6 . The In-cylinder pressure of the experiment and the simulation have a good consistency and the average deviation is less than $3.56 \%$ for $\mathrm{B} 0$ and $3.95 \%$ for B20. The CFD model was deemed to be effectively calibrated, as stated in. Thus, the effects of biodiesel blends on combustion, and exhaust emissions have been investigated by using experimental methods with the CFD model. 


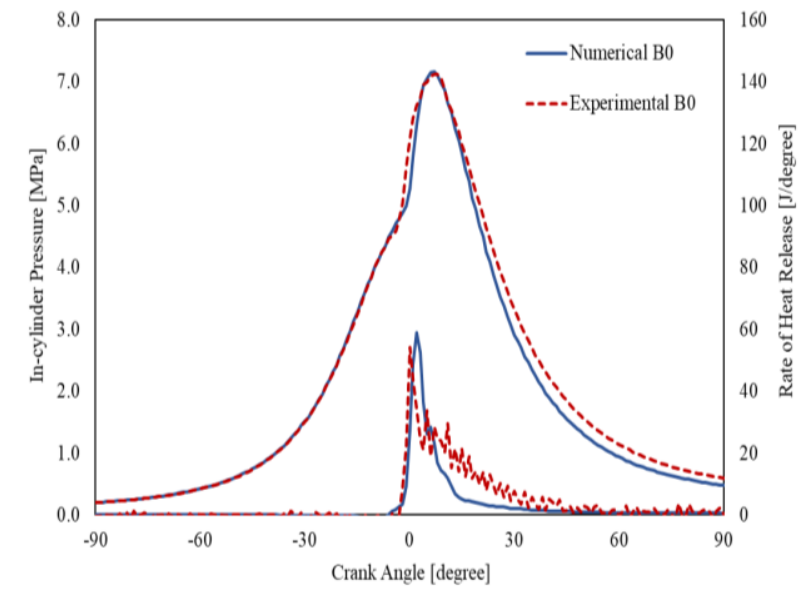

Figure 5. CFD model validation with experimental result for B0 case.

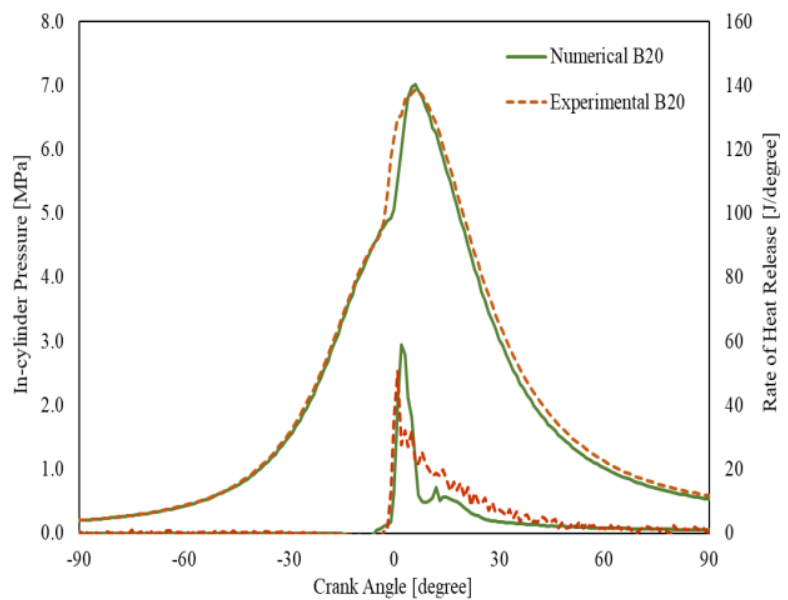

Figure 6. CFD model validation with experimental result for B20 case.

Table 5 shows the experimental and numerical gross IMEP, peak firing pressure (PFP), CA10, CA50, and CA90 of the B0 and B20 fuel blends. The gross IMEP value of the B20 fuel blend is lower than neat diesel. This is an expected situation as the LHV of B20 is lower than B0. The PFP of the CFD model is $7.17 \mathrm{MPa}$ for $\mathrm{B} 0$ and $7.03 \mathrm{MPa}$ for $\mathrm{B} 20$. There is a $2 \%$ difference compared to the experimental pressure. The PFP value is reduced by $2.7 \%$ with the $\mathrm{B} 20$ fuel blend. B20 has a shorter ignition delay than B0. 10\%, 50\%, and 90\% mass-burn fraction represented by CA10, CA50 and CA90 [41]. The change of these values depends on the cetane number of the fuel. High cetane fuel has a shorter ignition delay in compression ignition engines. Shorter CA50 and CA90 values were obtained with B20 fuel.
Table 5. Experimental and Numerical performance results of B0 and B20 biodiesel blend.

\begin{tabular}{lcccc}
\hline & \multicolumn{2}{c}{ Experimental } & \multicolumn{2}{c}{ Numerical } \\
\hline & B0 & B20 & B0 & B20 \\
\hline IMEP $_{\text {g (bar) }}$ & 6.43 & 6.39 & 6.04 & 5.95 \\
PFP (MPa) & 7.12 & 6.93 & 7.17 & 7.03 \\
PFP (degree) & 7.31 & 7.00 & 7.31 & 7.12 \\
CA10 (degree) & 0 & 0.07 & 0.24 & 0.07 \\
CA50 (degree) & 7.08 & 5.68 & 7.21 & 5.68 \\
CA90 (degree) & 44.1 & 40.8 & 45.1 & 40.7 \\
\hline
\end{tabular}

The in-cylinder characteristic of the engines is related to the air and fuel mixing process and the evaporation of the fuel, the combustion chamber geometry, and the properties of the fuel. The distribution of equivalence ratio inside the cylinder for $\mathrm{B} 0$ and $\mathrm{B} 20$ is shown in fig. 7. It is presented in this figure during fuel injection and when fuel injection is completed. The geometry of the piston bowl is unusual. It can be seen that this geometry is insufficient to direct the fuel. Both fuel blends showed similar characteristics in terms of mixture formation.

The in-cylinder temperature distributions were captured at four different crank angles as $-10^{\circ}, 0^{\circ},+5^{\circ}$, $+30^{\circ}$ aTDC (fig. 8). B0 and B20 reach maximum temperatures around $2700 \mathrm{~K}$. This temperature is the local maximum value. In-cylinder mean temperature reaches a maximum of about $1400 \mathrm{~K}$. The distribution of fuel in the cylinder is similar for B0 and B20, as the B0 and B20 fuels exhibit similar temperature distribution characteristics. The only difference is that as the B20 fuel moves further towards the cylinder center, the in-cylinder temperature has also increased at the cylinder center.

Fig 9 illustrates the Turbulent kinetic energy for B0 and $\mathrm{B} 20$ fuels from $+20^{\circ} \mathrm{bTDC}$ to $+30^{\circ}$ aTDC. It is seen incylinder TKE distribution that the piston bowl is insufficient to guide the fuel-air mixture. The fuel spray hits the piston wall and is plastered. This situation is an issue for two different fuels. This may result in increased soot emissions. Due to the different viscosity values of the fuels, a small difference was observed in the TKE values. 


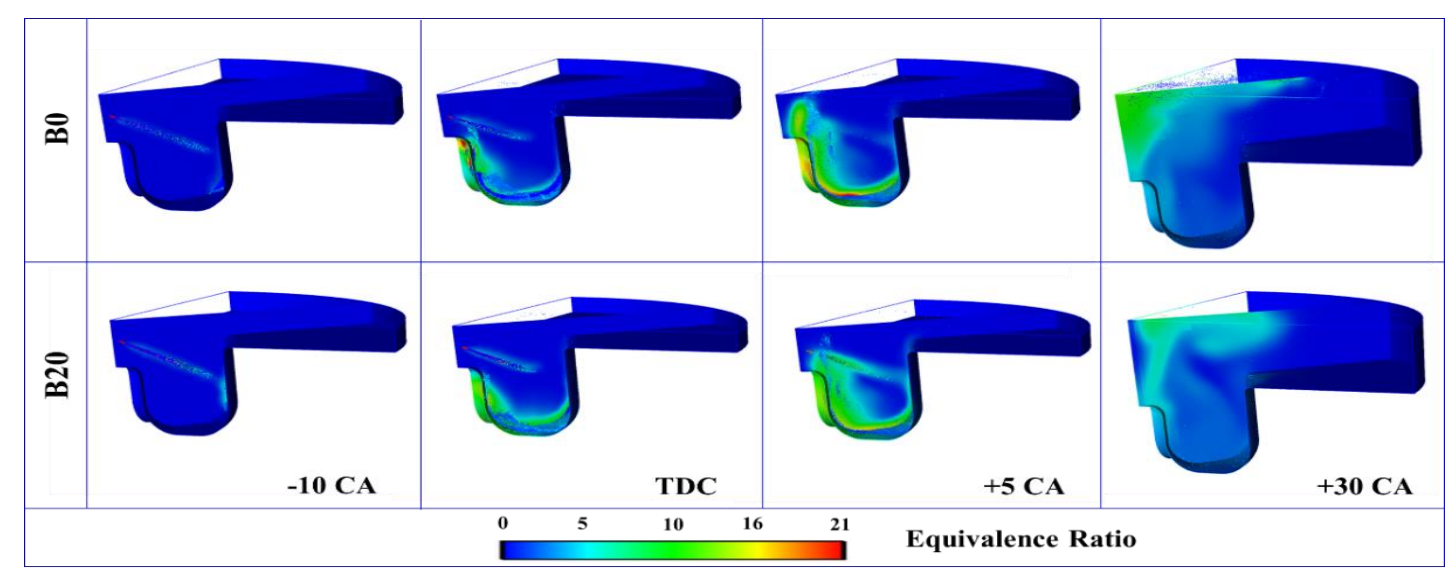

Figure 7. Equivalence ratio distribution for B0 and B20 fueled engines at various crank angles.

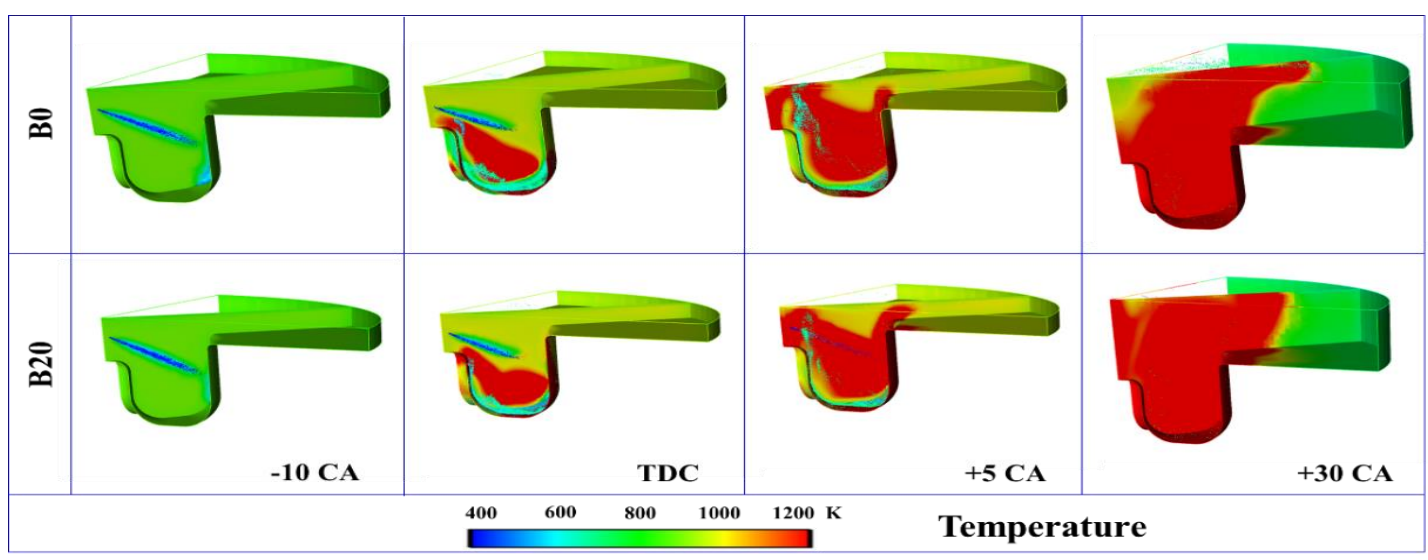

Figure 8. In-cylinder temperature distribution for B0 and B20 fueled engines at different crank angles.

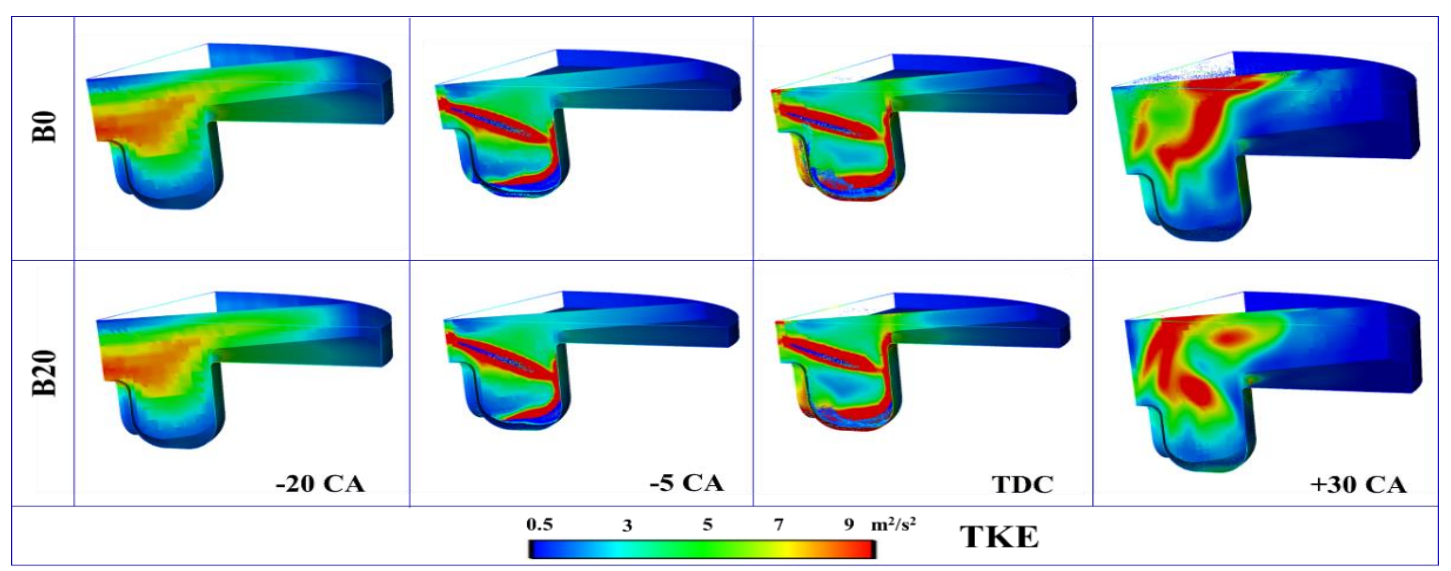

Figure 9. Turbulent kinetic energy for B0 and B20 fueled engines at different crank angles.

\subsection{Emission Characteristics}

Numerical studies have been performed to better understand the combustion and emission formation of neat diesel and B20 biodiesel. $\mathrm{NO}_{\mathrm{X}}$, soot, and $\mathrm{CO}$ emissions were calculated with the CFD simulation. Numerical and experimental emission results were compared to understand the accuracy of the model and also to investigate the influence of the B20 fuel blend. The percentage of the error has been not exceeded
$4.39 \%$ for both fuels and $\mathrm{NO}_{\mathrm{X}}$, soot, and $\mathrm{CO}$ emissions (fig. 10).

B20 fuel blend emits more $\mathrm{NO}_{\mathrm{X}}$ emissions. B20 fuel emits $1.85 \mathrm{~g} / \mathrm{kWh}$ of $\mathrm{NO}_{\mathrm{X}}$ emissions that is $5.5 \%$ higher than neat diesel. However, in terms of soot and $\mathrm{CO}$ emissions, the results are in favor of B20. The soot emission and CO emission of B20 fuel are 1.9 and 14.4 $\mathrm{g} / \mathrm{kWh}$ respectively, while it is $22.7 \%$ lower for $\mathrm{CO}$ and $15.6 \%$ lower for soot emission compared to B0 fuel. 

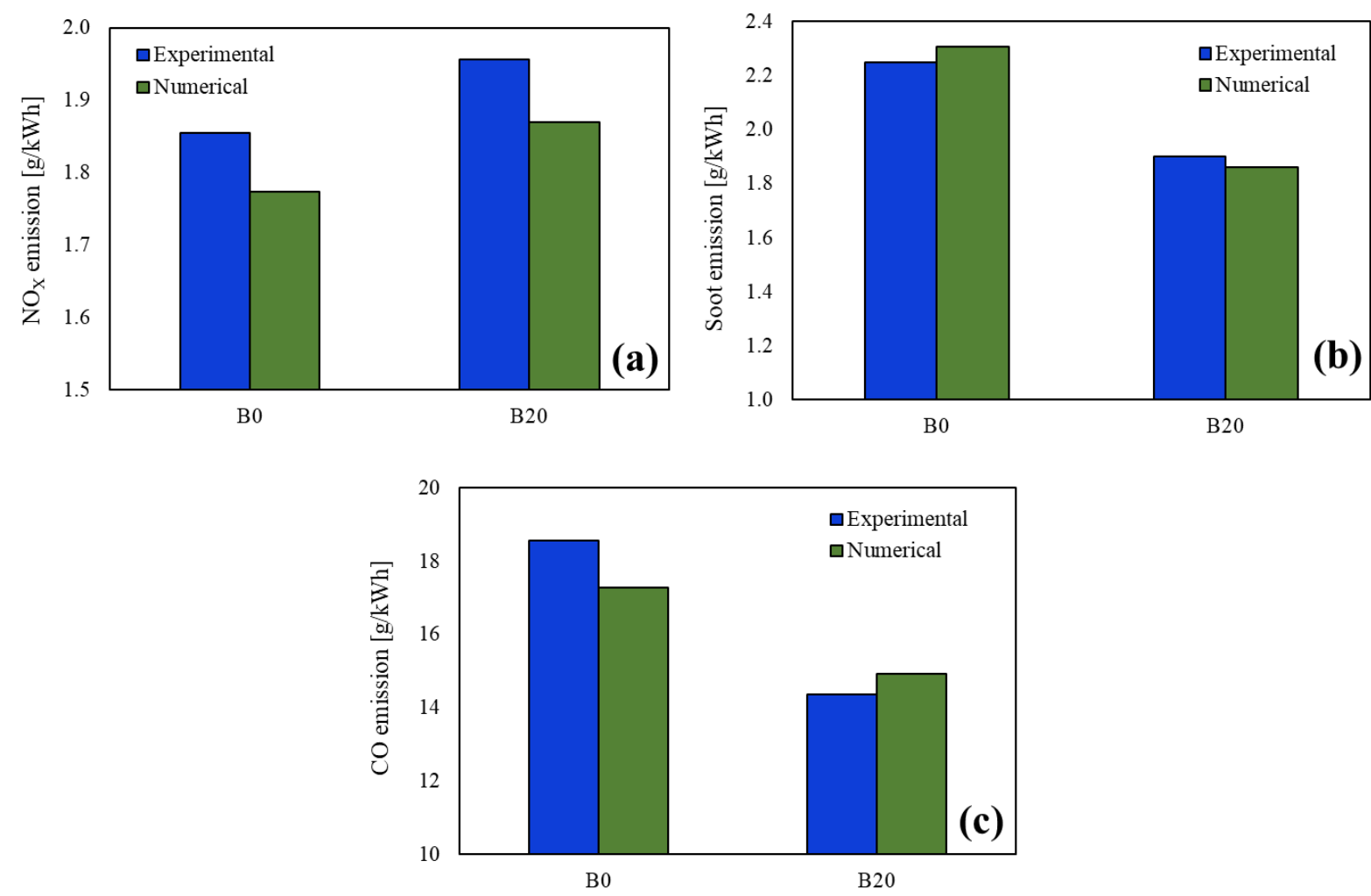

Figure 10. Comparison of experimental and numerical a) $\mathrm{NO}_{\mathrm{X}}$, b) soot and c) $\mathrm{CO}$ emission results of $\mathrm{B} 0$ and B20.

\section{CONCLUSIONS}

Waste cooking oil-based biodiesel in a CI engine is promising due to its low emissions and low cost and contribution to recycling. In the present study, the exhaust emission and engine performance of biodiesel and diesel fuel were examined experimentally and numerically. The CFD model was established to evaluate a test engine characteristic such as in-cylinder fluid flow, mixture preparation, temperature distribution, and emission formation. Validation results of the CFD model against neat diesel and B20 fuel blends showed that this model was able to predict combustion and performance with reasonable accuracy.

Biodiesel that produced from waste cooking oil can be used blended with diesel without modifications either in the engine or in the injection system. The CI engine fueled with B20 blend emits lower $\mathrm{CO}$ and soot emission by $22.7 \%$, and $15.6 \%$ respectively compared to neat diesel. However, the B20 fuel blend increases the $\mathrm{NO}_{\mathrm{x}}$ emission by $5.5 \%$.

\section{Acknowledgment}

The author would like to thank Dr. Görkem Kökkülünk, Mr. Cenk Kaya, and Mr. Zafer Aydın from Yildız Technical University, Turkey for providing support and experimental data for this study. The author gratefully acknowledges the Convergent Science Company for providing the academic version of the Converge CFD software.

\section{Nomenclature}

AMR Adaptive mesh refinement

aTDC After top dead center

B0 Neat diesel

B20 20\% biodiesel $+80 \%$ diesel blend

B100 Neat biodiesel

bTDC Before top dead center

CA Crank angle

CA10 Crank angle position at which $10 \%$ of the heat is released

CA50 Crank angle position at which $50 \%$ of

the heat is released

CA90 Crank angle position at which $90 \%$ of the heat is released

CFD Computational fluid dynamics

EVO Exhaust valve opening

IMEP $_{\mathrm{g}}$ Gross indicated mean effective pressure

IVC Intake valve closing

KH Kelvin-Helmholtz

NTC No Time Counter

PFP Peak firing pressure

RNG Renormalization Group

RT Rayleigh-Taylor

SAGE Detailed chemistry solver

SOI Start of injection

TDC Top dead center

TKE Turbulent kinetic energy

WCO Waste cooking oil 


\section{REFERENCES}

[1] Knothe, G., \& Razon, L. F. (2017). Biodiesel fuels. In Progress in Energy and Combustion Science (Vol. 58, pp. 36-59). Elsevier.

[2] Mohd Noor, C. W., Noor, M. M., \& Mamat, R. (2018). Biodiesel as alternative fuel for marine diesel engine applications: A review. In Renewable and Sustainable Energy Reviews (Vol. 94, Issue April, pp. 127-142). Elsevier.

[3] Tropecêlo, A. I., Caetano, C. S., Caiado, M., \& Castanheiro, J. E. (2016). Biodiesel production from waste cooking oil over sulfonated catalysts. Energy Sources, Part A: Recovery, Utilization and Environmental Effects, 38(2), 174-182.

[4] Phan, A. N., \& Phan, T. M. (2008). Biodiesel production from waste cooking oils. Fuel, 87(17-18), 3490-3496.

[5] More, G. V., Koli, S. R., Rao, Y. V. H., Prasad, P. I., \& Rao, B. N. (2020). Effect of compression ratio on compression ignition engine with RUCO biodiesel/ diethyl ether/ diesel fuel blends. Energy Sources, Part A: Recovery, Utilization and Environmental Effects, 1-20.

[6] Ma, F., \& Hanna, M. A. (1999). Biodiesel production: A review. Bioresource Technology, 70(1), 1-15.

[7] Wong, Y. C. (2014). Biodiesel production from used cooking oil. Oriental Journal of Chemistry, 30(2), 521-528.

[8] Dubey, A., Prasad, R. S., \& Singh, J. K. (2020). An Analytical and Economical Assessment of the Waste Cooking Oil based Biodiesel using Optimized Conditions on the Process Variables. Energy Sources, Part A: Recovery, Utilization and Environmental Effects, 1-16.

[9] Al-Dawody, M. F., Jazie, A. A., \& Abdulkadhim Abbas, H. (2019). Experimental and simulation study for the effect of waste cooking oil methyl ester blended with diesel fuel on the performance and emissions of diesel engine. Alexandria Engineering Journal, 58(1), 9-17.

[10] Ulusoy, Y., Arslan, R., Tekin, Y., Sürmen, A., Bolat, A., \& Şahin, R. (2018). Investigation of performance and emission characteristics of waste cooking oil as biodiesel in a diesel engine. Petroleum Science, 15(2), 396-404.

[11] Patel, C., Chandra, K., Hwang, J., Agarwal, R. A., Gupta, N., Bae, C., Gupta, T., \& Agarwal, A. K. (2019). Comparative compression ignition engine performance, combustion, and emission characteristics, and trace metals in particulates from Waste cooking oil, Jatropha and Karanja oil derived biodiesels. Fuel, 236(September 2018), 1366-1376.

[12] Wei, L., Cheng, R., Mao, H., Geng, P., Zhang, Y., \& You, K. (2018). Combustion process and NOx emissions of a marine auxiliary diesel engine fuelled with waste cooking oil biodiesel blends. Energy, 144, 73-80.
[13] Abed, K. A., El Morsi, A. K., Sayed, M. M., Shaib, A. A. E., \& Gad, M. S. (2018). Effect of waste cooking-oil biodiesel on performance and exhaust emissions of a diesel engine. Egyptian Journal of Petroleum, 27(4), 985-989.

[14] Zareh, P., Zare, A. A., \& Ghobadian, B. (2017). Comparative assessment of performance and emission characteristics of castor, coconut and waste cooking based biodiesel as fuel in a diesel engine. Energy, 139, 883-894.

[15] Qureshi, M. W. G., Khan, Z. M., Hussain, M., Ahmad, F., Shoaib, M., \& Qasim, M. (2019). Experimental evaluation of a diesel engine for combustion, performance and exhaust emissions with fuel blends derived from a mixture of fish waste oil and waste cooking oil biodiesel. Polish Journal of Environmental Studies, 28(4), 2793-2803.

[16] Chen, H., Xie, B., Ma, J., \& Chen, Y. (2018). NOx emission of biodiesel compared to diesel: Higher or lower? Applied Thermal Engineering, 137(December 2017), 584-593.

[17] Chaurasiya, P. K., Singh, S. K., Dwivedi, R., \& Choudri, R. V. (2019). Combustion and emission characteristics of diesel fuel blended with raw jatropha, soybean and waste cooking oils. Heliyon, 5(5), e01564.

[18] Li, H., Yang, W., Zhou, D., \& Yu, W. (2018). Numerical study of the effects of biodiesel unsaturation on combustion and emission characteristics in diesel engine. Applied Thermal Engineering, 137(January), 310-318.

[19] Yangaz, M. U., Özdemir, M. R., \& Şener, R. (2019). Combustion performance of hydrogenenriched fuels in a premixed burner. Environmental Technology (UK), 1-12.

[20] Sener, R., Özdemir, M. R., \& Yangaz, M. U. (2019). Effect of the geometrical parameters in a domestic burner with crescent flame channels for an optimal temperature distribution and thermal efficiency. Journal of Thermal Engineering, 5(6), 171-183.

[21] Sener, R., Yangaz, M. U., \& Gul, M. Z. (2020). Effects of injection strategy and combustion chamber modification on a single-cylinder diesel engine. Fuel, 266, 117122.

[22] Hawi, M., Elwardany, A., Ookawara, S., \& Ahmed, M. (2019). Effect of compression ratio on performance, combustion and emissions characteristics of compression ignition engine fueled with jojoba methyl ester. Renewable Energy, 141, 632-645.

[23] Venu, H., Raju, V. D., \& Subramani, L. (2019). Combined effect of in fluence of nano additives, combustion chamber geometry and injection timing in a DI diesel engine fuelled with ternary (diesel-biodiesel-ethanol) blends. Energy, 174, 386-406.

[24] Ismail, T.M., Lu, D., Ramzy, K., El-salam, M. A., Yu, G., \& Elkady, M. A. (2019). Experimental 
and theoretical investigation on the performance of a biodiesel-powered engine from plant seeds in Egypt. Energy, 189, 116197.

[25] Asadi, A., Zhang, Y., Mohammadi, H., Khorand, H., Rui, Z., Hossein, M., \& Vahabzadeh, M. (2019). Combustion and emission characteristics of biomass derived biofuel, premixed in a diesel engine: A CFD study. Renewable Energy, 138, 79-89.

[26] Rajak, U., Nashine, P., Singh, T. S., \& Verma, T. N. (2018). Numerical investigation of performance, combustion and emission characteristics of various biofuels. Energy Conversion and Management, 156(August 2017), 235-252.

[27] Zhao, F., Yang, W., Yu, W., Li, H., Sim, Y. Y., Liu, T., \& Tay, K. L. (2018). Numerical study of soot particles from low temperature combustion of engine fueled with diesel fuel and unsaturation biodiesel fuels. Applied Energy, 211(May 2017), 187-193.

[28] Akcay, M., Yilmaz, I. T., \& Feyzioglu, A. (2020). Effect of hydrogen addition on performance and emission characteristics of a common-rail CI engine fueled with diesel/waste cooking oil biodiesel blends. Energy, 212, 118538.

[29] Utlu, Z. (2007). Evaluation of biodiesel fuel obtained from waste cooking oil. Energy Sources, Part A: Recovery, Utilization and Environmental Effects, 29(14), 1295-1304.

[30] Richards, K. J., Senecal, P. K., \& Pomraning, E. (2019). CONVERGE 2.4 Manual (p. 1078). Convergent Science.

[31] Li, Z., Wang, Y., Geng, H., Zhen, X., Liu, M., Xu, S., \& Li, C. (2019). Parametric study of a diesel engine fueled with directly injected methanol and pilot diesel. Fuel, 256(April), 115882.

[32] Senecal, P. K., Pomraning, E., Richards, K. J., Briggs, T. E., Choi, C. Y., McDavid, R. M., \& Patterson, M. A. (2003). Multi-dimensional modeling of direct-injection diesel spray liquid length and flame lift-off length using cfd and parallel detailed chemistry. SAE Technical Papers.

[33] Luo, Z., Plomer, M., Lu, T., Som, S., Longman, D. E., Sarathy, S. M., \& Pitz, W. J. (2012). A reduced mechanism for biodiesel surrogates for compression ignition engine applications. Fuel. 99(1), 143-153.

[34] Amsden, A. A. (1997). KIVA-3V: A BlockStructured KIVA Program for Engines with Vertical or Canted Valves. LA Report.

[35] Frassoldati, A., D’Errico, G., Lucchini, T., Stagni, A., Cuoci, A., Faravelli, T., Onorati, A., \& Ranzi, E. (2015). Reduced kinetic mechanisms of diesel fuel surrogate for engine CFD simulations. Combustion and Flame, 162(10), 3991-4007.

[36] Reitz, R.D. (1987). Mechanisms of Atomization Processes in High-Pressure Vaporizing Sprays. Atomization and Spray Technology, 3, 309337.

[37] Schmidt, D. P., \& Rutland, C. J. (2000). A New Droplet Collision Algorithm. Journal of Computational Physics, 164(1), 62-80.

[38] Heywood, J. (1988). Internal combustion engine fundamentals. In McGraw Hill.

[39] Hiroyasu, H., \& Kadota, T. (1976). Models for Combustion and Formation of Nitric Oxide and Soot in Direct Injection Diesel Engines.

[40] Kaya, C., \& Kökkülünk, G. (2020). Biodiesel as alternative additive fuel for diesel engines: An experimental and theoretical investigation on emissions and performance characteristics. Energy Sources, Part A: Recovery, Utilization and Environmental Effects, 1-23.

[41] Zhang, Z., Liu, X., Liu, H., Wu, Y., Zaman, M., Geng, Z., Jin, C., Zheng, Z., Yue, Z., \& Yao, M. (2021). Effect of soybean oil/PODE/ethanol blends on combustion and emissions on a heavy-duty diesel engine. Fuel, 288(October 2020), 119625. 